\title{
Етнологія
}

УДК 316.36:316.334.55](477.53)«182»

DOI 10.31652/2411-2143-2019-27-82-87

\section{Олена Бороденко}

Полтавський національний педагогічний університет ім. В.Г. Короленка, кандидат історичних наук, доцент (Україна)

\section{Шлюбна локація: спроба реконструкції історій сільських сімей Роменського повіту Полтавської губернії першої половини XIX століття}

Анотація. У дослідженні зроблено спробу показати шлюбну локацію сільських родин Роменського повіту Полтавської губернії першої половини XIX cm. Виокремити осібні приклади матримоніальних союзів патрилокального, матрилокального та проміжного локаційних типів, указати на можливі сімейні переміщення впродовж існування подружжя.

Ключові слова: домогосподарство, сім'я, сповідні розписи, шлюб, шлюбна локація, церковні обшуки.

Відповідно до звичаїв українського населення Полтавської губернії після вінчання, весільного святкування в будинку нареченої та проведення обряду «братъ продаеть сестру» подружжя від"їжджало в домогосподарство чоловіка [2, с. 246], тобто визначало сімейну локацію (від лат. locatio - розміщення, місцезнаходження). Такий союз, коли дружина переходила в родину чоловіка прийнято називати патрилокальним [18]. Проте так було не завжди, декотрі 3 наречених-чоловіків все ж таки залишалися в домогосподарстві дружини, а окремі мігранти навіть переїжджали в інший населений пункт, тоді родина ставала матрилокальною. Очевидно, існувала й проміжна фрорма локації, коли подружня пара проживала осібно, ані в жіночій, ані чоловічій родині.

Із-поміж спеціальних історико-демографічних методик спробували використати положення однієї з них, розробленої в середині XX ст. фрранцузьким демографом Луї Анрі - «метод відтворення історії сімей» $[1$, с. 82, 122]. Цей метод доволі схожий із мікроісторичним аналізом сімей, який ґрунтується на генеалогіях і реконструкціях історій окремих родин і прив'язує події до конкретних індивідів, які носять одне прізвище. За допомогою цих методик можливо відтворити у всіх деталях механізми утворення, росту, розпаду окремих сімей, розпочинаючи від хрещення, шлюбу і закінчуючи похоронами їхніх членів. Методика, розроблена фрранцузьким вченим, дозволяє дослідити ці зміни протягом як мінімум одного століття та визначити природу демографрічних коливань впродовж певного періоду часу [13, с. 29].

У нашому дослідженні простежимо історію створення родин різних шлюбно-локаційних типів: патрилокального, матрилокального та проміжного. Щоправда, відсутність інфрормативної джерельної бази в необхідному об'ємі для розкриття генеалогічних відмінностей окремо взятих сімей за сто років зумовили представлення осібних родинних картин дещо неповно. Проте це не було головною метою дослідження, адже передусім прагнули показати сімейну локаційність. Лише одну родину Сисоя Стефранова Бартоша з с. Процівка продемонструємо в розрізі зміни трьох поколінь. Одночасно визначимо час створення та існування сімей, покажемо випадки повторної шлюбності, вікові інтервали між народженням дітей, вінчанням і періодом першої народжуваності, антропологічні відмінності тощо.

За відправну точку в нашому дослідженні візьмемо шлюбні/церковні обшуки («обыскные книги») с. Миколаївка за різні роки [10; 11]. Потім, використовуючи матеріали сповідних розписів осібних сіл Роменського повіту Полтавського губернії, визначимо локацію новостворених родин. Зокрема, прослідкуємо матрилокальність миколаївських наречених або переміщення подружніх пар після вінчання в інші села, наприклад, Калинівку, Процівку, Рогинці. Для розкриття указаного питання використаємо матеріали церковних книг визначеного регіону: сповідні розписи Роменського повіту за 1749 та 1847 рр., с. Калинівка за 1831-1854рр., с. Процівка - 17551859 рр., с. Рогинці - 1799-1859 pp. [19; 3; 4; 5; 6; 7; 8; 9].

Уперше «обыскные книги» було введено в 1765 р. [14, с. 189-190], скоректовано призначення та форму написання указами 1802 р. [15, с. 230] та 1837 р. [16, с. 947-948]. Церковна документація укладалася священиком парафіяльної церкви напередодні кожного обряду вінчання та тим самим підтверджувала наявність необхідних умов, визначених законом, для здійснення цього таїнства [20, с. 643]. У шлюбних обшуках визначалося територіальне походження, сімейний стан, відсутність перепон до укладання шлюбу. Сповідні розписи 
запроваджувалися 3 метою встановлення церковного контролю за мораллю парафіян та фріксували відвідування парафріянами сповіді та причастя [17, с. 123].

Отже, спочатку спроектуємо зародження однієї з родин, представленої шлюбними обшуками с. Миколаївка. Так, 7 травня 1839 р. відбулося вінчання 28-річного вдового дворянина Григорія Дмитрова Бабкіна з с. Калинівка з 27-річною козацькою вдовою Мариною Басарабкою [11, арк. 108]. Про патрилокальне переміщення молодих дізнаємося з матеріалів сповідних розписів с. Калинівка за 1842 р. Подружжя оселилося у домогосподарстві Бабкіна та за цей час у родині народився син Полікарп, який зареєстрований чотирирічним [4, арк. 64-64 зв.]. Наведена шлюбна локація вказує на патрилокальний характер, адже дружина переїхала у домогосподарство свого чоловіка та ще й в інше село. До року або двох років сімейного життя з'явилася спільна дитина.

Історію наступної патрилокальної родини прослідкуємо від народження нареченого Сисоя Стефанова (Степанова) Бартоша із с. Процівка, покажемо його родословну в декілька поколінь - за 110 років. Сповідні розписи 1749 р. показують домогосподарство Бартошенків. Це була складна або мультифокальна за типом родина, яка складалася принаймні 3 чотирьох нуклеарних ядер - сімей братів, одне з яких представляло родину Сисоєвого діда. Домову спільноту очолював Григорій Петров Бартошенко (40 років), його дружиною була Агафрія Павловна (30 років). У них був однорічний син Федір. Друге нуклеарне ядро очолював 30-річний дід Сисоя Яків Петрович. Бабусею була 25-річна Параскева Алексеєва [19, арк. 71 зв.]. На час укладання церковної книги в сім'ї діда було троє дітей: майбутній батько Сисоя Стефран - 10 років, Анастасія - 9 років та Анна 7 років. Яків Петрович Бартошенко помирає наприкінці $60-\mathrm{x}$ років, адже в 1770 р. Параскева Олексіївна Бартошиха вказана вдовою-очільнецею домової спільноти, у якій проживав син Стефан з дружиною. Остання згадка про бабусю датується 1787 р. Записана вона 88-річною, хоча в попередніх реєстрах за 1778, 1784, 1785 рр. її вік коливався від 89 до 94 років [5, 143, 193, 199, 224 зв.].

Наступне нуклеарне ядро демонструвало сім'ю третього брата з роду Бартошенків: 28 річного Федіра Петрова, його дружини, 26-річної Анни Стефанової, та двох дітей (Афанасія 6 років, Орини 1 року). Четверта проста сім'я наймолодшого брата Мартина Петрова (26 років) показана ним, його дружиною Єфросинією Григорівною (22 роки) та однорічною донькою Марфою. Отже, домогосподарство Сисоєвого діда було складним за типом і складалося 3 чотирьох нуклеарних ядер рідних братів Бартошенків.

у 1755 р. Сисоєв батько Стефан Бартош або ще тоді Бартошенко, був неодружений, однак за сповідними розписами йому вже 23 роки. Він одружився, ймовірно, між 1756-1758 рр., позаяк в 1759 р. він фігурує 28-річним чоловіком у шлюбі з 25-річною Марфою [5, арк. 4 зв., 11]. Вочевидь, дітей у цієї родини довгий час не було. У церковних реєстрах за 1760, 1761, 1770, 1778 рр. дітей не записано. Потім у 1784-1785 рр. з'являється 18-19-річна донька Агафія. Можемо припустити, що вона була прийнята на виховання як осиротіла або ж якась родичка. У 1789 р. одноразово згадується онука Ксенія - 7 років, можливо також нерідна, хоча вже в 1790 p. Стефан Яковлєв 58 років і Марфа Лук'яновна (55 років) - знову бездітні. У 1791 р. батько Сисоя зареєстрований із новою 56-річною дружиною Тетяною Власовою. Дітей не представлено [5, арк. 193, 199, 244,271$]$.

Імовірно, Сисой народився в 1792 р. у родині «военного» (козака) Стефана Яковлєва Бартоша. Уперше однорічний хлопчик на ім'я «Сосой» фрігурує в сповідних розписах 1793 р. На час народження сина батькові було близько 59-60 років, а матері - Тетяні Іванівні - 37. Виходить, що це вже третя дружина Стефрана, молодша за нього на 23 роки. Окрім однорічного Сисоя у родині було ще двоє дітей: Єфросинія -6 років і Трохим 5 років, мабуть, діти від попереднього шлюбу матері [6, арк. 35]. У пізніших редакціях сповідних розписів за 18021803 рр. Трохим фігурує по-батькові - Данилов [6, арк. 158 зв., 181 зв.]. Це вказує на те, що брат був рідний тільки по матері. Отож, з'ясовуємо, що для матері шлюб з його батьком теж був не першим. Сестру Єфросинію вже в 1796 р. не згадано, мабуть, десь в 9-10 років вона померла [6, арк. 72, 158 зв., 181]. Стефан був очільником мультифокальної домової спільноти, адже на подвір'ї проживала ще й нуклеарна родина 36-річної Настасії Федорової Бартошевої, названою карабенеркою, сімейний статус якої чітко не зазначено. Припускаємо, що жінка була солдаткою, а ії чоловік перебував на військовій службі, тому не був присутній на сповіді та відповідно не записаний до церковного реєстру. Прізвище жінки вказує на родинні зв'язки з очільником, однак ступінь спорідненості не можливо встановити.

У 10-11-річному віці Сисой залишився без батька. Ще в 1802 р. 68-річний Стефан Яковлєв був згаданий, а в 1803 р. домогосподарство вже очолювала вдова Тетяна Іванівна Бартошка, яка чомусь за віком не постарішала, а навпаки помолодшала, оскільки нібито йй було 35 років. Хлопець з роками дорослішав і за нашими підрахунками одружився у 18-19 років. Вінчання двох першошлюбників відбулося 6 лютого 1810 р. у миколаївській Різдво-Богородицькій церкві. 


\section{Наукові записки ВДПУ ім. М.М. Коцюбинсъкого}

Дружиною стала Єфросинія Коговда [10, арк. 198]. Подружня пара утворила патрилокальну сім'ю, адже наречена переїхала у Сисоєве село - Процівку. У 1811 р. домову спільноту розширеного типу очолювала 51-річна овдовіла Тетяна Бартошка, разом із якою проживали Сисой (22 років) і його дружина Єоросинія 20 років, а також неодружений другий син Трохим 28 років. Проте процівський парафріяльний священик вже у 1818 р. не зазначає присутність Трохима. Скоріше за все він одружився та утворив матрилокальну родину або ж помер [7, арк. $6,63]$. Бачимо, що вік молодят, передусім чоловіка, очевидно завищений.

У сім'ї Сисоя народжувалися діти. Першою зафріксованою у церковному реєстрі 1818 р. дитиною був 9-річний син Петро. Щоправда, хлопчик прожив недовго, позаяк у 1820 р. і далі не згадується. Натомість у 1825 р. парафіяльний священик, який не вчасно вносив відомості про дітей, показує вже троє дітей: Мотрону - 12 років, Лукію 9 років та Анну 5 років. Невдовзі в 1833 р. остання дівчинка так само зникає з реєстраційних записів, очевидно через смерть. Упродовж 1833-1835 рр. у складі нуклеарної частини сім'ї було показано двоє дівчат [7, арк. 131, 191 зв., 212 зв., 223 зв., 228]. Однак вже в 1836 р. присутня лише 17-річна Лукія [8, арк. 2 зв.]. Сестра Мотрона, напевно, вийшла заміж та як більшість дівчат опісля весільних святкувань перейшла в домогосподарство чоловіка. Подібно з церковної документації зникає й інша донька. Лукія (20 років) ще проживала в 1839 р. разом із батьками, 50-річним Сисоєм Стефановичем та 44-річною Єфросинією Іванівною. Потім, очевидно, вона вступила в шлюб, а батьки вже без дітей проживали разом ще рік, однак в 1845 р. Сисоєва дружина померла [8, 137 арк.].

Отже, перша патрилокальна родина Сисоя Стефанова Бартоша за 35 років існування мала четверо дітей, але двох утратила за малолітства. Віковий інтервал між одруженням і народженням первістка-хлопчинка був близько року. Різниця у віці між дітьми становила 3-4 роки. Останнє народження дівчинки Анни припадає десь на 1819 р., коли Єфросинії Іванівні було близько 38 років, а Сисою - 40 років. Це дає змогу визначити час створення сім'ї, тобто період між вступом у шлюб та останнім народженням, протяжність якого варіювалася в залежності від шлюбного віку подружжя [1, с. 124]. Тому можемо стверджувати, що час утворення матримоніального союзу Сисоя Бартоша становив близько 19-20 років. Матеріали сповідних розписів показали антропонімічні зміни, зокрема прізвища, адже дід записаний Бартошенком, а його син та онук Сисой по-різному. Для прикладу, в 1825 р. Сисой зареєстрований Бартошенком, а в 1831 р. і далі - Бартошом [7, арк. 131, 178].

Чоловік не довго був у жалобі, навряд чи дотримався піврічного жалобного терміну, адже в 1845 р. він проживав у своєму домогосподарстві, але 3 другою дружиною - Феодосією Тимофрієвою. Жінка, напевно, за сімейним станом була вдовицею, оскільки перейшла в його двір не сама. Разом із нею зареєстровано двох їі дітей: Домнікію - 11 років та Андрія - 7 років. Проте у 1854 р. донька дружини вже не записана. Очевидно, досягнувши шлюбного віку, перейшла в чоловікове домогосподарство. Значився лише 13-річний син Андрій. Остання згадка про Сисоя, знайдена нами, датується 1859 р. Тоді чоловік був ще живим, записаний 69-річного віку, хоча йому повинно було б бути 67-68 років, і проживав разом із 48-річною другою дружиною Феодосією. Різниця у віці між подружжям становила близько 20 років. Дітей вже не зареєстровано, адже син Андрій зникає з аркушів церковних книг, можливо знову ж таки через смерть або раннє одруження, створення матрилокальної сім'ї, щоправда, як показало наше дослідження, така вірогідність незначна [8, арк. 171 зв., 189 зв., 210 зв.]. Припускаємо, що хлопець, як нерідний син господаря двору, міг податися на заробітки. Отже, Сисой Бартош був принаймні двічі одружений, на відміну від батька, який мав три шлюби.

Звернімо увагу на наступну подружню пару, яка вірогідно створила родину проміжного локаційного типу. Павло Ігнатов Подрез з с. Житне 21 січня 1835 р. одружився на миколаївській Домнікії Ігнатовій Зубка [11, с. 83 зв.]. У книзі з реєстрацій сповідей населення за 1847 р. знаходимо згадку про двір Василя Артемова Олексієнка (30 років) і його дружини Марії Наумової (29 років). Вони проживали разом із 4-річним сином Яковом. Не відомо у яких родинних відносинах були Подрези з Олексієнками, можливо підсусідками, але житнянський 33-річний згаданий вище Павло Ігнатов із дружиною Домнікією Ігнатовою, 34 роки, і чотирма дітьми: Євдокією - 10 років, Петром 6 років, Дар'єю - 5 років та Феклою 2 років, зареєстровані у цьому домогосподарстві [3, арк. 1040 арк.]. Отже, сім'я Павла Подреза проживала в домовій спільноті, яка явно не вказує належність ані до чоловікової, ані жінчиної родини.

У наступній частині нашої розвідки спробуємо простежити матрилокальність окремих сімейних союзів. Правдоподібно, що такі сім'ї були малочисельними. Із 14 сімей, локацію яких нам вдалося дослідити, лише у двох випадках чоловік-наречений переїхав жити у домову спільноту своєї дружини. Першою була дворянська родина Костянтина Яковлєва Авраменка 3 с. Рогинці. Після вінчання 10 листопада 1829 р. із миколаївською дворянкою Параскевою, донькою корнета Івана Кота (Котова), новостворена сім'я так і залишилася на постійному місці 
проживання у селі нареченої. Очевидно, для Костянтина це був вигідний шлюб, адже він одружився на доньці губернського секретаря [3, арк. 1050 зв.].

Досліджуючи батьківську родину нареченого за сповідними розписами указаного вище року, виявляємо, що 17-річний Костянтин зареєстрований у домогосподарстві 57-річної вдовипоручиці Єлизавети Григорівни Авраменкової. Разом із ними у домовій спільноті проживала нуклеарна сім'я кадетської вдови Марфи Григорівни Авраменкової (60 років). Ії̈ дітьми були: Устин Федоров 19 років, Костянтин - 17 років, Федір - 12 років. Указано, що всі вони «живущие въ хуторе Авраменкова» [9, арк. 36 зв.]. У такому складі, однак без згадування Костянтина Яковлєва, домова спільнота залишалася впродовж 1829-1833 рр. Вже у 1835 р. Устину не показано. Відомо, що в 1836-1840рр. у домогосподарстві проживали дві вдови, але без дітей [9, арк. 100, 139, 151 зв., 229 зв., 323 зв., 340 зв.]. Очевидно, поступово всі хлопці одружилися й не залишилися у рогинцівському хуторі, а створили матрилокальні або сім'ї проміжного типу.

У сповідних розписах с. Миколаївка 1847 р. знаходимо подвір'я 36-річного колезьського реєстратора Костянтина Івановича Авраменка та його дружини Параскеви Іванівни 33 років. Домова спільнота була нуклеарного типу та налічувала ще трьох дітей: Василя 14 років, Данила 9 років та Єлисея 5 років [3, арк. 1037]. Очевидно, переїзд Костянтина з хуторянського домогосподарства був пов'язаний з отриманням найнижчого цивільного чину. Можливо, спочатку молодята проживали разом із батьками нареченої, але потім, із появою дітей, відділилися в окреме домогосподарство. За майже двадцятилітню історію розвитку, напевно, сім'я збагатилася, адже у Костянтина Авраменка були володіння у с. Миколаївка та хуторі Соколова, де проживало 26 осіб дворових і поміщицьких селян [3, арк. 1051]. Так, 3 матрилокальної утворилася сім'я проміжного типу. Натомість, мати дружини, вдова корнета Івана Власова Кота 66-річна Ксенія Никифорівна, проживала в окремому дворі [3, арк. 1036].

На матрилокальний характер сім'ї вказує домогосподарство Романа Іванова Бабенка, 33 роки, та його дружини-однолітки Ксенії Зиновіївни, які проживали спільно з Тимофрієм - 8 років, Григорієм - 4 років та Оникієм 2 років. Подвір'я Бабенків зареєстроване у миколаївській сповідальній книзі за 1847 р. [3, арк. 1040 зв.]. Подружжя повінчалося 27 січня 1835 р. Відомо, що наречений був удівцем із с. Калинівка, а наречена походила з родини Зиновія Зубка та була першошлюбницею [11, арк. 83 зв.]. Поряд із ними у 1847 р., напевно, проживала новостворена сім'я сестри Ксенії, також матрилокального типу, 22-річної Тетяни Зиновієвої, яка була заміжньою за Ісидором Кириловим Лавриком 24 років [3, арк. 1040 зв.]. Дітей у сестринському нуклеарному ядрі не зазначено.

Отже, в обох матрилокальних сім'ях простежено певні особливості їхнього розвитку. У першому випадку спостерігаємо ранньовіковий дворянський шлюб, адже на час вінчання нареченому було близько 17, а нареченій - 14-15 років. У другому - вінчання подружжя після 20річного віку. У Авраменків різниця у віці між чоловіком і дружиною становила 2-3 роки, а Бабенки були однолітками. Віковий інтервал між вінчанням і первістком становив близько 3 років у першій сім'ї. У другій родині такий інтервал був річний. В обох матримоніальних союзах зареєстровано по троє дітей. Міждитячий віковий інтервал коливався від 2 до 5 років.

Підсумовуючи, зауважимо, що у дослідженні спробували реконструювати історії окремих сімей патрилокального, матрилокального і проміжного локаційного типів, а родинну картину патрилокального типу Сисоя Бартоша представили у трипоколінних змінах за 110 років. Сільські матримоніальні союзи територіально належали до Роменського повіту Полтавської губернії першої половини XIX ст. Відтворення історій окремих сімей показали: переважали патрилокальні, малочисельно зустрічалися матрилокальні та родини проміжного локаційного типу; переміщень зазнавали сім'ї різних соціальних прошарків; шлюбна локація могла змінюватися впродовж росту родини та пов'язана із демографічними процесами, передусім заселеністю, структурними та типологічними змінами домових спільнот, а також природніми, тобто тими, що відбувалися у родинному середовищі, зокрема дітонародженням, осібними одруженнями ії членів або смертністю. Не виключаємо, що на переміщення сімей могли впливати соціально-економічні процеси, що відбувалися в сільській громаді, зміна професійних інтересів тощо. Вікова різниця між подружжям коливалася від одного до восьми років, а найбільша становила 23 роки. У більшості новостворених сімей діти народжувалися впродовж перших років спільного життя. Міждитячий інтервал коливався від 2 до 5 років.

\section{ДЖЕРЕЛА ТА ЛІТЕРАТУРА:}

1. Анри Л., Блюм А. Методика анализа в исторической демографрии [пер. с фр. С. Хока и Ю. Егоровой]. Москва: РГГУ, 1997. 207 с.

2. Арендаренко Н. Записки о Полтавской губерніи, Николая Арендаренка, составленныя въ 1846 году. Въ трехъ частях. Ч. ІІ. Полтава: В типографріи Губернскаго Правленія, 1849. 393 с.

3. Держархів Сумської області. Ф. 960. Оп. 3. Спр. 1. 1780 арк. 


\title{
Наукові записки ВДПУ ім. М.М. Кочюбинсъкого
}

4. Держархів Сумської області. Ф. 960. Оп. 3. Спр. 126. 290 арк.

5. Держархів Сумської області. Ф. 960. Оп. 3. Спр. 225. 280 арк.

6. Держархів Сумської області. Ф. 960. Оп. 3. Спр. 226. 287 арк.

7. Держархів Сумської області. Ф. 960. Оп. 3. Спр. 228. 235 арк.

8. Держархів Сумської області. Ф. 960. Оп. 3. Спр. 229. 226 арк.

9. Держархів Сумської області. Ф. 960. Оп. 3. Спр. 274. 435 арк.

10. Держархів Сумської області. Ф. 1036. Оп. 1. Спр. 3. 62 арк.

11. Держархів Сумської області. Ф. 1036. Оп. 1. Спр. 5. 118 арк.

12. Ласлетт П. Семья и домохозяйство: исторический поход // Брачность, рождаемость, семья за три века: Сб. статей / [под ред. А. Г. Вишневского и И. С. Кона]. Москва: Статистика, 1979. C. $132-158$.

13. Ливи Баччи, Массимо. Демографическая история Европы. Серия «Становление Европы» [пер. с итал. А. Миролюбовой]. СПб.: «Александрия», 2010. 304 с.

14. Полное собрание законов Российской империи, с 1646 года [в 45 т.]. (ПСЗРИ). СПб.: Тип. II Отд. Собственной Е.И. В. Канцелярии.1830. Собраніе первое. Т. XVII. 1115 с.

15. ПСЗРИ. Собраніе первое. Т. XXVII. 1120 с.

16. ПСЗРИ. Собраніе второе. Т. ХІІ. Ч. 2. 1067 с.

17. Романова О. Сповідні книги Київської митрополії XVIII ст. Як спосіб церковного контролю за мораллю парафріян // Український історичний журнал. 2008. №4. С. 122-148.

18. Федорова Н. А., Каримова Л. М. Историческая демография: теория и метод. Учебное пособие. - Казань: Изд-во Казанского университета, 2012.

19. Центральний державний архів України у м. Києві. Ф. 127. Оп. 1015. Спр. 15.818 арк.

20. Энциклопедический словарь Брокгауза и Ефрона. Т. XXIa (1897): Нэшвилль - Опацкий. С. 643. URL: https://ru. wikisource.org/w/index.php?title=\% D0\%A4\%D0\%B0\%D0\% B9\%D0\%BB: Encyclopedicheskii_slovar_tom_21_a. djvu\&page=182\#filehistory

\section{Елена Бороденко}

Полтавский национальный педагогический университет им. В.Г. Короленко, кандидат исторических наук, доцент,(Украина)

\section{Брачная локация: попытка реконструкции историй сельских семей Роменского уезда Полтавской губернии первой половины XIX века}

Аннотация. В исследовании предпринята попытка показать брачную локацию сельских семей Роменского уезда Полтавской губернии первой половины XIX в. Выделить отдельные примеры матримониальных союзов патрилокального, матрилокального и промежуточного локационных типов, указать на возможные семейные перемещения на протяжении существования супружеств.

Ключевые слова: брак, брачная локация, домохозяйство, семья, исповедные росписи, церковные обыски.

\author{
ABSTRACT \\ Olena Borodenko \\ Poltava V.G. Korolenko National Pedagogical University, \\ PhD ( History), Associate Professor (Ukraine)

\section{Marriage location: an attempt to reconstruct the histories of rural families in Romny district of the Poltava province in the first half of the 19th century}

It was made an attempt to show the marriage location of rural families in the Romny district of the Poltava province in the first half of the 19th century, to highlight individual examples of matrimonial unions of the patrilocal, matrilocal and intermediate location types, to point out possible family movements during the existence of matrimonies. The materials of marriage searches and confessional murals, to reproduce the stories of individual rural families, and the story of one - Sisoy Stefanova Bartosh, to present in the context of the change of three generations over 110 years were used. Other issues also be disclosed: features of population registration by priests in church documentation; the conceptual apparatus of historical and demographic nature, which the author uses, the gender-age differences of entry into the first family union; possible causes that affected the movement of families; the time period of the creation and existence of families; the social origin of the spouses; the age difference between the spouses; the repeated marriage rate, the number of children; the age intervals 
between childbirth, and also between the wedding and the birth of the firstborn; anthroponymic features and etc. The study showed that the patrilocal prevailed, matrilocal and families of intermediate location type were few in number; movements of families of different social groups; marital status could change during family growth and it is associated with demographic processes, primarily, population, structural and typological changes in communities, as well as natural, that is, those that occurred in the family environment, in particular, in childbirth, marriage or mortality; the movement of families could be influenced by socio-economic processes occurring in the rural community and etc. The age difference between the spouses ranged from one to eight years, and the largest was 23 years. The interstitial interval between children ranged from 2 to 5 years.

Key words: marriage, marriage location, household, family, confessionals, church searches.

\section{REFERENCES:}

1. Anri L., Blyum A. Metodika analiza v istoricheskoy demografii [per. s fr. S. Khoka i Yu. Yegorovoy]. Moskva: RGGU, 1997. $207 \mathrm{~s}$.

2. Arendarenko N. Zapiski o Poltavskoy gubernii, Nikolaya Arendarenka, sostavlennyya v 1846 godu. V trekh chastyakh. Ch. II. Poltava: V tipografii Gubernskago Pravleniya, 1849. 393 s.

3. Derzharkhiv Sumsjkoji oblasti (DASO). F. 960. Op. 3. Spr. 1. 1780 ark.

4. Derzharkhiv Sumsjkoji oblasti. F. 960. Op. 3. Spr. 126. 290 ark.

5. Derzharkhiv Sumsjkoji oblasti. F. 960. Op. 3. Spr. 225. 280 ark.

6. Derzharkhiv Sumsjkoji oblasti. F. 960. Op. 3. Spr. 226. 287 ark.

7. Derzharkhiv Sumsjkoji oblasti. F. 960. Op. 3. Spr. 228. 235 ark.

8. Derzharkhiv Sumsjkoji oblasti. F. 960. Op. 3. Spr. 229. 226 ark.

9. Derzharkhiv Sumsjkoji oblasti. F. 960. Op. 3. Spr. 274. 435 ark.

10. Derzharkhiv Sumsjkoji oblasti. F. 1036. Op. 1. Spr. 3. 62 ark.

11. Derzharkhiv Sumsjkoji oblasti. F. 1036. Op. 1. Spr. 5. 118 ark.

12. Laslett P. Semya i domokhozyaystvo: istoricheskiy pokhod // Brachnost, rozhdaemost, semya za tri veka: Sb. statey / [pod red. A. G. Vishnevskogo i I. S. Kona]. Moskva: Statistika, 1979. S. 132 158.

13. Livi Bachchi, Massimo. Demograficheskaya istoriya Yevropy. Seriya «Stanovlenie Yevropy» [per. s ital. A. Mirolyubovoy]. SPb.: «Aleksandriya», 2010. 304 s.

14. Polnoe sobranie zakonov Rossiyskoy imperii, s 1646 goda [v 45 t.]. (PSZRI). SPb.: Tip. II Otd. Sobstvennoy Ye.I. V. Kantselyarii.1830. Sobranie pervoe. T. XVII. $1115 \mathrm{~s}$.

15. PSZRI. Sobranie pervoe. T. XXVII. $1120 \mathrm{~s}$.

16. PSZRI. Sobranie vtoroe. T. XII. Ch. 2. $1067 \mathrm{~s}$.

17. Romanova O. Spovidni knyghy Kyjivsjkoji mytropoliji XVIII st. Jak sposib cerkovnogho kontrolju za morallju parafijan // Ukrajinsjkyj istorychnyj zhurnal. 2008. № 4. S. 122-148.

19. Tsentraljnyj derzhavnyj arkhiv Ukrainy u m. Kyievi. F. 127. Op. 1015. Spr. 15.818 ark.

20. Entsiklopedicheskiy slovar Brokgauza i Yefrona. T. XXla (1897): Neshvill - Opatskiy. S. 643. Yelektronniy resurs: https://ru.wikisource.org/w/index.php?title= \%D0\%A4\%D0\%B0\%D0\% B9\%D0\%BB: Encyclopedicheskii_slovar_tom_21_a.djvu\&page=182\#filehistory 